\title{
IAMJ
}

INTERNATIONAL

AYURVEDIC

MEDICAL JOURNAL

Review Article

ISSN: 2320-5091

Impact Factor: 6.719

\section{HRIDROGA - AN OUTLOOK THROUGH SAMANYA LAKSHANA}

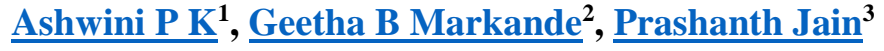 \\ ${ }^{1}$ II Year P.G Scholar, ${ }^{2}$ Associate Professor, ${ }^{3} \mathrm{HOD}$, Professor \\ Dept. of P.G Studies in Roganidana Evam Vikriti Vigyan, Alva's Ayurveda Medical College, Moodbidri, \\ Karnataka, India
}

Corresponding Author: ashwini15495@gmail.com

\section{https://doi.org/10.46607/iamj2409092021}

(Published Online: September 2021)

Open Access

(C) International Ayurvedic Medical Journal, India 2021

Article Received: 07/08//2021 - Peer Reviewed: 25/08/2021 - Accepted for Publication: 26/08/2021

\section{Check for updates}

\section{ABSTRACT}

Hridroga (cardiovascular diseases) are the major causes of death globally, taking an estimated 17.9 million lives each year. In view of increasing incidence of cardiac disorders in the present era, there is a need to understand the disease more elaborately. Ayurveda has a unique approach towards understanding and diagnosing diseases. Diagnosis must be done by proper analysis of presenting symptoms of a disease. By the thorough knowledge regarding these signs and symptoms, right diagnosis can be done before planning any treatment. Ayurveda has given utmost importance for diagnosis with due consideration of Lakshanas. Hritshoola (chest pain), Vaivarnya (cyanosis), Moorcha (syncope), Shwasa (dyspnea), Kasa (cough) are the cardinal features of Hridroga. By knowing the whole concept of Lakshanas, diagnosis can be done at an earlier stage.

Keywords: Hridroga, Cardiovascular diseases, Samanya Lakshanas

\section{INTRODUCTION}

Cardiovascular diseases are the group of disorders of heart and blood vessels that include coronary heart disease, heart failure, rheumatic heart disease, congenital heart disease, cardiomyopathies and other conditions ${ }^{1}$.
Any structural or functional abnormalities which hinders the normal functions of Hridaya can be considered as Hridroga (cardiovascular diseases). Classical texts of Ayurveda explain various types of Hridroga caused by Vata, Pitta, Kapha and Krimi. In spite of the 
description of heart diseases in Ayurveda, understanding the disease in modern way is the need of the hour. According to WHO, cardiovascular diseases are the major causes of death globally, taking an estimated 17.9 million lives each year ${ }^{2}$. According to Ayurveda, Vaivarnya, Moorcha, Jwara, Kasa, Hikka, Shwasa, Asyavairasya, Trisha, Pramoha, Chardi, Kaphotklesha, Ruja, Aruchi are the cardinal features of Hridroga. Patients with cardiovascular diseases present with symptoms like chest pain and may even end up in death. The symptoms caused by heart disease result most commonly from myocardial ischemia, from disturbance of the contraction and/or relaxation of the myocardium, from obstruction to blood flow, or from an abnormal cardiac rhythm or rate ${ }^{3}$. Knowledge regarding these symptoms can help a Physician to diagnose the disease at an earlier stage and thus plan for the treatment. Since the description of Hridroga in Ayurveda is brief, there is a need for more clarification. Here, Samanya Hridroga Lakshanas are taken into consideration and an attempt is made to explain the important Lakshanas of this disease with reference to variety of cardiac diseases.

Materials and methods: Materials related to Hridroga, and cardiovascular diseases are collected from Ayurvedic Samhitas and textbooks of modern medicine respectively. Relevant matters are also obtained from medical journals.

Hridroga Samanya Lakshanas: According to Charaka Samhita, Vaivarnya, Moorcha, Jwara, Kasa, Hikka, Shwasa, Asyavairasya, Trisha, Pramoha, Chardi, Kaphotklesha, Ruja and Aruchi are the Samanya Lakshanas of Hridroga ${ }^{4}$.

\section{Vaivarnya}

Neela and Shyava are two among the Vaikarika Varnas explained in the literatures, which can be seen in patients with cardiovascular diseases. When Oshta turns Pakwajambu Varna, it is a morbid sign ${ }^{5}$. Cyanosis is more a sign than a symptom of heart disease. In central cyanosis due to cardiac cause, the extremities and tongue are all cyanosed. In congenital heart diseases, central cyanosis occurs due to the mixing of arterial and venous blood within the heart or outside ${ }^{6}$.
Peripheral cyanosis occurs when the peripheral circulation is slow. Differential cyanosis presents with half part of the body having natural complexion and other half having unnatural complexion, as seen in Patent Ductus Arteriosus. Vaivarnya can also be understood as anaemia, which can be seen in conditions like infective endocarditis, angina pectoris, ischemic heart disease, etc.

\section{Pramoha-Moorcha}

Moha is a state of confusion which leads to Moorcha (syncope). Patients with syncope may experience a prodrome (pre-syncope) in which the patient may have symptoms like lightheadedness, visual disturbance, nausea and sweating. These symptoms may last for a few seconds before the syncopal event. Syncope is a transient loss of consciousness that occurs when the cardiac output is not sufficient to maintain the cerebral blood flow ${ }^{7}$. Patient loses consciousness over seconds. Morbid signs include the patient fainting again and again while being taken out of the bed ${ }^{8}$. Postural syncope, due to orthostatic hypotension occurs due to cardiac causes, which prevents the body from responding rapidly enough to pump more blood while standing up. Syncope is commonly seen in cardiac arrhythmias, valvular heart disease, acute myocardial infarction, pulmonary hypertension, sick sinus syndrome, etc.

Jwara: Fever can be seen as a symptom in cardiac diseases like infective endocarditis, pericarditis, acute myocardial infarction, etc. In acute myocardial infarction, there will be mild rise in temperature within 24 hours and can last up to a week ${ }^{9}$.

Kasa-Hikka: In Charaka Samhita, there is a mentioning about Vidradhi in Hridaya and in that context, Kasa is told as one of the symptoms ${ }^{10}$. In case of heart failure, there will be decreased ventricular output, which results in the accumulation of fluid in the lungs. As the lungs become congested, excess fluid leaks into the alveoli. Coughing is body's natural response to clear the bronchial passages to relieve congestion ${ }^{11}$. Hemoptysis occurs usually in advanced stages of cardiac diseases. It is seen in conditions like valvular heart diseases. Diseases like myocardial infarction can cause vagus nerve irritation leading to hiccups. 


\section{Shwasa}

In Charaka Samhita, while mentioning Vidradhi in Hridaya, Shwasa is mentioned as one of the symptoms ${ }^{12}$. Urdhwashwasa is very common in massive myocardial infarction. There will be cardiac failure leading to reduction in pumping ability of the heart which in turn causes pulmonary oedema. These diseases may predispose to Urdhwashwasa. Signs and symptoms of pulmonary oedema including breathing difficulty, frothy sputum, etc can be seen in Urdhwashwasa ${ }^{13}$. Many cardiovascular diseases present with symptoms like exertional dyspnea, orthopnea, paroxysmal nocturnal dyspnea, Cheynestokes respiration. Dyspnea occurs due to many factors like increased work of breathing, reduced vital capacity, bronchial narrowing, etc. It is one of the cardinal manifestations of cardiovascular diseases, which is also seen in many other conditions like pulmonary disease, obesity and anxiety ${ }^{14}$. Cardiac causes of dyspnea include valvular disease, heart failure, cardiac arrhythmias and cardiomyopathy.

\section{Chardi, Asyavairasya, Aruchi}

Symptoms of gastrointestinal tract like Chardi, Asyavairasya and Aruchi can be seen in Hridroga. Chest pain with vomiting is seen in cardiovascular diseases like myocardial infarction, cardiac arrhythmias. As Hridaya is a vital organ which nourishes all other cells of the body, any morbidity in Hridaya can lead to the impairment of other organs of the body including the digestive system. In case of congestive heart failure, loss of appetite, nausea, fullness after meals and distension of abdomen are the common features. Vomiting occurs occasionally.

Ruja

Cardiac disease is the most important among the different causes of precordial pain, the most common being myocardial infarction. It can also be due to other causes like gastritis, any musculoskeletal conditions, etc. Chest pain of cardiac origin can radiate to different sites like inner aspect of left arm to little finger, left or both sides of neck and jaw, left scapular region, right shoulder, arm and epigastrium ${ }^{15}$. In Samhitas, there is mentioning of different characters of pain caused by Doshaja types of Hridroga. Vataja Hridroga presents with Toda, Shoola, Bheda type of pain; Daha, Chosha etc can be seen in Pittaja Hridroga and patient feels as if loaded with a stone (Ashmaavrita) in Kaphaja Hri$\operatorname{drog} a^{16}$. Modern Science also explains various types of pain for different cardiovascular diseases like ischemic pain is vague, crushing, bursting, lancinating, burning type; pain in acute myocardial infarction is sudden, severe, crushing, prolonged and is usually experienced at rest; anginal pain occurs during exertion and is relieved with rest ${ }^{17}$.

\section{DISCUSSION}

Vaivarnya, Moorcha, Jwara, Kasa, Hikka, Shwasa, Asyavairasya, Trisha, Pramoha, Chardi, Kaphotklesha, Ruja and Aruchi are the Samanya Lakshanas of Hridroga. These are the symptoms pertaining to Doshaja, Sahaja, Margavaranajanya and Krimija Hridroga. A patient with Hridroga can present with any of these Lakshanas either individually or combined. A Physician who is well versed in all these Lakshanas can come to proper diagnosis without any fail. In case of serious heart disease, a great variety of symptoms may arise, which may or may not be connected with the cardiovascular system and care should be taken in order to identify the exact cause.

\section{CONCLUSION}

Symptoms of cardiovascular diseases ranges from chest pain, syncope to death. Many of these symptoms can also occur due to non-cardiac causes. So, to diagnose Hridroga, critical analysis of all its Lakshanas is necessary. Ayurveda has a unique way of understanding and diagnosing diseases. Diagnosis has to be done by proper analysis of Lakshanas of a disease. By the complete knowledge of these Lakshanas, right diagnosis can be done before planning any treatment protocol. Among all the symptoms, chest pain is one of the major manifestations of dreadful diseases like coronary artery diseases. So, every chest pain should be treated as cardiovascular origin considering the grave prognosis. Thus, by knowing the whole concept of Lakshanas, a Physician can do the diagnosis at an earlier stage and can succeed in his clinical practice. 


\section{REFERENCES}

1. https://www.who.int/cardiovascular_diseases/about_cvd/en/

2. https://www.who.int/health-topics/cardiovascular-diseases/\#: :text=Cardiovascular\%20diseases\%20(CVDs)\%20are\%20the, heart\%20disease $\% 20$ and $\% 20$ other\%20conditions.

3. Fauci AS, Kasper DL, Hauser SL, Jameson JL, Loscalzo J. Harrison's Principles of Internal Medicine. Twentieth edition. New York: McGraw-Hill Medical Publishing Division; 2018.Volume II. p.1649.

4. Vaidya Jadavji Trikamji Acharya, Charaka Samhita by Agnivesa with Ayurveda Dipika Commentary of Cakrapanidatta, Chikitsa Sthana; Chapter 26, Verse 78. Varanasi: Chaukambha Krishnadas Academy, 2015; p.602.

5. Vaidya Jadavji Trikamji Acharya, Charaka Samhita by Agnivesa with Ayurveda Dipika Commentary of Cakrapanidatta, Indriya Sthana; Chapter 1, Verse 23. Varanasi: Chaukambha Krishnadas Academy, 2015; p.356.

6. Krishna Das KV. Textbook of Medicine. Fifth edition. Jaypee Brothers Medical Publishers(P) LTD; 2008.p.744

7. Krishna Das KV. Textbook of Medicine. Fifth edition. Jaypee Brothers Medical Publishers(P) LTD; 2008.p.744

8. Vaidya Jadavji Trikamji Acharya, Charaka Samhita by Agnivesa with Ayurveda Dipika Commentary of Cakrapanidatta, Indriya Sthana; Chapter 7, Verse 19. Varanasi: Chaukambha Krishnadas Academy, 2015; p.366.

9. Mohan H. Textbook of Pathology, Harsh Mohan. Seventh Edition. Jaypee Brothers Medical Publishers(P) Ltd; 2010.p.414

10. Vaidya Jadavji Trikamji Acharya, Charaka Samhita by Agnivesa with Ayurveda Dipika Commentary of Cakrapanidatta, Sutra Sthana; Chapter 17, Verse 101. Varanasi: Chaukambha Krishnadas Academy, 2015; p.104.

11. https://www.verywellhealth.com/coughing-and-heartfailure-cardiac-cough-explained-3896488

12. Vaidya Jadavji Trikamji Acharya, Charaka Samhita by Agnivesa with Ayurveda Dipika Commentary of Cakrapanidatta, Sutra Sthana; Chapter 17, Verse 101. Varanasi: Chaukambha Krishnadas Academy, 2015; p.104.
13. Vaidya Jadavji Trikamji Acharya, Charaka Samhita by Agnivesa with Ayurveda Dipika Commentary of Cakrapanidatta, Chikitsa Sthana; Chapter 17, Verse 4951. Varanasi: Chaukambha Krishnadas Academy, 2015; p.535.

14. Fauci AS, Kasper DL, Hauser SL, Jameson JL, Loscalzo J. Harrison's Principles of Internal Medicine. Twentieth edition. New York: McGraw-Hill Medical Publishing Division; 2018.Volume II.p.1649

15. Krishna Das KV. Textbook of Medicine. Fifth edition. Jaypee Brothers Medical Publishers(P) LTD; 2008.p.744

16. Pt. Hari Sadasiva Sastri Paradakara, Ashtangahrudaya of Vagbhata with Commentaries of Sarvangasundara of Arunadatta and Ayurvedarasayana of Hemadri, Nidana Sthana; Chapter 5, Verse 39-42. Varanasi: Chaukamba Sanskrit Sansthan, 2016.p.482

17. Krishna Das KV. Textbook of Medicine. Fifth edition. Jaypee Brothers Medical Publishers(P) LTD; 2008. p.744

\section{Source of Support: Nil Conflict of Interest: None Declared}

How to cite this URL: Ashwini P K et al: Hridroga - An Outlook Through Samanya Lakshana. International Ayurvedic Medical Journal \{online\} 2021 \{cited September 2021\} Available from: http://www.iamj.in/posts/images/upload/2084_2087.pdf 